Gi respons på artikler gjennom artiklenes kommentarfelt på tidsskriftet.no.

Innleggene publiseres fortløpende på Tidsskriftets nettside og et utvalg

av innleggene publiseres også i papirutgaven i spalten «Brev til redaktøren».

Redaksjonen forbeholder seg retten til å foreta redaksjonelle endringer.

Forfattere av vitenskapelige artikler har tilsvarsrett, jf. Vancouver-gruppens regler

\section{Re: Ulike retningslinjer for behandling av prostatakreft}

Jeg leste med interesse Bjerklund Johansens kommentar om ulike retningslinjer for behandling av prostatakreft i Tidsskriftet (1). Jeg kan ikke vurdere den kritikken han fremsetter mot de norske retningslinjene, men jeg kjenner godt igjen beskrivelsen av hvordan internasjonale retningslinjer tas imot på nasjonalt nivå.

Bjerklund Johansen skriver at det ofte er forskjeller på norske og europeiske kliniske retningslinjer når det gjelder tverrfaglighet og vitenskapelige kvalifikasjoner i forfatterpanelene, arbeidsmetode og leserkrets. Ved utarbeiding av europeiske retningslinjer, gjennomgår anbefalingene ekstern internasjonal fagfellevurdering før publisering, hvilket bidrar til å unngå interessekonflikter for personer og grupper, og reduserer faren for ukritisk omtale av egen forskning og egne referanser.

I tillegg til nasjonale retningslinjer, finnes det på enkelte sykehus lokale retningslinjer. I blant finnes det til og med varierende retningslinjer innenfor samme sykehus for samme tilstand. Naturligvis kan det finnes årsaker til varierende behandling mellom sykehus på grunn av lokal kompetanse og geografi, men jeg mener det meste burde være det samme for alle pasienter. Som Bjerklund Johansen skriver: Forfattere av norske retningslinjer bør begrunne hvorfor de avviker fra internasjonale retningslinjer. Her synes jeg Danmark er et foregangsland, og spesielt innen kardiologi. Danmark er delt inn i fem regioner, som hver har en farmasøytisk komité, men det danske kardiologiske samfunnet har klart å ene hele landet til delte retningslinjer (2) som dekker nesten alle hjerte- og karsykdommer. Den danske Society of Cardiology oppdaterer disse retningslinjer hvert år, og de brukes på alle danske sykehus som nasjonale felles retningslinjer. Det oppfattes av kolleger i Danmark som en nasjonal standard av Sundhetsstyrelsen og andre offentlige etater for å referere til hva som er forsvarlig klinisk praksis.

Nå har jeg konsentrert diskusjonen på kardiologi, men jeg tror situasjonen er den samme i de fleste spesialiteter, hvilket støttes av kommentaren fra Bjerklund Johansen om prostatakreft. Det må være en enorm ødsling av resurser om lokale eksperter gjør om samme vurderinger som allerede er gjort av internasjonale eksperter som har produsert retningslinjer som har gjennomgått en omfattende ekstern, internasjonal fagfellevurdering før publisering. I tillegg er det vanligvis de mest erfarne og kvalifiserte kolleger i sine respektive spesialiteter som spanderer meget tid på denne oppgaven.

En pasient med en sykdomstilstand skal ha beste behandling uavhengig av hvor han eller hun er. Følsomhet til retningslinjer har vist på bedre resultat for pasientene (3-5). Vel gjennomarbeidede, internasjonale retningslinjer bør følges for beste medisinske resultat, men i blant trengs en tilpassing til hvert enkelt lands regulatoriske og økonomiske forhold. Slike tilpasninger bør begrunnes.

Jeg har hatt største delen av min kliniske virksomhet i Sverige og skulle ønske å kunne avslutte med hvor bra det er i Sverige, men det kan jeg ikke. Det er (nesten) like ille i Sverige. Har vi for mange eksperter?

\section{Stefan Agewall}

stefan.agewall@medisin.uio.no

Stefan Agewall (f. 1960) er overlege og professor i kardiologi ved Oslo Universitetssykehus og Universitetet i Oslo.

Ingen oppgitte interessekonflikter.

\section{Litteratur}

1. Johansen TEB. Ulike retningslinjer for behandling av prostatakreft. Tidsskr Nor Legeforen 2015; 135: 924-5.

http://nbv.cardio dk/(3.7.2015)

3. Jonathan De Blois J, Morten Wang Fagerland M, Morten Grundtvig M et al. ESC guidelines adherence is associated with improved survival in patients from the Norwegian Heart Failure Registry. Eur Heart J Cardiovasc Pharmacother 2015 $1: 31-6$.

4. Cotte $L$, Bénet $T$, Vanhems $P$ et al. The effect of adherence to guidelines for initial antiretroviral therapy on 1-year outcomes: a French cohort study. BMC Infect Dis 2014; 14: 596

5. Mehta RH, Chen AY, Alexander KP et al. Doing the right things and doing them the right way: association between hospital guideline adherence, dosing safety, and outcomes among patients with acute coronary syndrome. Circulation 2015; 131: $980-7$

\section{Re: Pasientens eller helsepersonellets helsetjeneste?}

«For første gang i historien er det laget en stortingsmelding om primærhelsetjenesten», skriver Hege Gjessing i sin leder i Tidsskriftet nr. 11/2015 (1). Men historien begynte ikke i år. For eksempel la jeg som helseminister for et par tiår siden frem en stortingsmelding om primærhelsetjenesten: St. meld. nr. 23 (1996-97) Trygghet og ansvarlighet - Om legetjenesten i kommunene og fastlegeordningen.

Men den var hverken den første eller siste stortingsmelding om primærhelsetjenesten. Primærhelsetjenesten ble heftig debattert på 1960- og 70-tallet og en rekke offentlige utredninger, innstillinger, stortingsmeldinger og lovforslag ble fremmet. Særlig viktig var naturligvis St.meld. nr. 85 (1970-71) Om helsetjenesten utenfor sykehus. I 1979 kom to viktige offentlige utredninger som omhandlet ulike sider av primærhelsetjenestene: NOU 1979: 28 Helseog sosialtjenesten i lokalsamfunnet. Oppgave og ansvarsfordeling. Finansieringsordning, og NOU 1979: 10 Helsepolitikken.

NOU-ene dannet sammen med høringsuttalelsene grunnlaget for utformingen av lovproposisjonen Ot. prp. 36 (1980-81) Om lov om helsetjenestene i kommunene, og senere Ot.prp. nr. 66 (1981-82) Om lov om helsetjenesten og sosialtjenesten i kommunene. Kommunehelsetjenesteloven ble iverksatt i 1984.

Erfaringene med loven og kommunehelsetjenestene ble drøftet i St. meld. nr. 36 (1989-90) Røynsler med lova om helsetenesta i kommunene hvor det konkluderes med at det ville være nyttig å få prøvd ut et listepasientsystem i Norge. Regjeringen fremmet forslag om en prøveordning med fast lege i fire kommuner (Ot.prp. nr. 64 (1990-91) Om lov om forsøk med listepasientsystem i kommunehelsetjenesten). Finansieringsordningene for allmennlegetjenesten ble gjennomgått i NOU 1992: 10 Finansieringsordninger for allmennlege- og fysioterapitjeneste. Og stortingsmeldingen om fastlegeordningen kom altså i 1997.

Dette er bare et utvalg. Linjer kunne trekkes enda lengre tilbake - og fremover i historien. Legeforeningens president har vel ikke allerede glemt St.meld. nr. 47 (2008-2009), Samhandlingsreformen - Rett behandling - på rett sted - til rett tid.?

Både som politisk og profesjonell aktør må Legeforeningen være vederheftig. Da kan presidenten ikke spre myter. Det foreligger flere lett tilgjengelige og gode oversikter over utviklingen - for eksempel i tidsskriftet Michael (2). Og med de staber presidenten rår over, skulle det heller ikke være så vanskelig å sjekke fakta før man griper til pennen. 